УДК 94 (477.7) «17»

DOI: https://doi.org/10.33782/2708-4116.2020.3.37

Сергій Аргатюк, Ігор Сапожников*

\title{
МІСЩЯ ПОХОВАНЬ ЖЕРТВ НКВС В ОДЕСІ: ОГЛЯД ПРЕСИ І ДОКУМЕНТІВ 1943 РОКУ
}

Анотація: Стаття присвячена огляду й аналізу деsких епізодів радянських репресій в Одесі, які мали місце у 1930-ті - на початку 1940-х рр., переважно через призму документів і місцевої преси. Цілий стос беззаперечних фактів про них був розкритий для широкої публіки у 1943 році, а потім у 1990-х - 2000-х роках, шляхом розкопок, перепоховання тіл загиблих і публікації документів, що сформувало у більшості одеситів сталий суспільний погляд на ці явища. Однак в останні роки вони стали піддаватися критиці і ревізії за кордоном, а для одеських вчених і краєзнавців сама тема почала зникати з порядку денного. Тому автори ще раз наводять матеріали стосовно того, що у 1943 р. були досліджені два місия поховань жертв розстрілів НКВС: на міському звалищі біля кургану Могила Татарська, неподалік 6-го км Овідіопольського шосе та на II-му християнському кладовищі. Для повнішого розкриття теми, републікуються дві газетні статті, в яких описані ці місия та виявлені там численні знахідки та факти, які прямо вказували на час, організаторів і виконавців.

Ключові слова: Одеса, міське звалище, курган Могила Татарська, Друге християнське кладовище, дослідження місць масових розстрілів, реакція місцевої преси

Про злочини радянського НКВС на Одещині у 1930-1940-х рр. написано чимало, але сьогодні все частіше друкуються роботи, в яких більшовицькі злодіяння відбілюють, перекручуючи факти і документи'. Показово, що такі дії спрямовані на перекладання вини за розстріли поляків під Смоленськом на німців, а за знищення мирного населення Одеси на румунів. Виходячи з сучасної міжнародної ситуації, поява «досліджень» такого роду є цілком очікуваною. Однак те, що одеський автор у новій книжці, присвяченій окупації міста під час Другої світової війни, не приділив уваги роботі Комісії з розслідувань й оприлюднених нею фактам², викликає подив. Справа у тому, що у 1943 р. вони мали широкий резонанс серед одеситів, жваво обговорювались, а деякі родини віднайшли серед загиблих своїх близьких. Саме тому ми змушені повернутися до теми трагедії біля Татарки та в інших місцях, звернувши особливу увагу на свідчення очевидців і власне місця злочинів, як обєкти досліджень і пам'яті. При цьому автори не торкатимуться аналогічних злочинів, які скоїли німецькі та румунські вояки у нашому країㄹ, а лише тих, які радянська влада навмисно при-

\footnotetext{
* Аргатюк Сергій Степанович - вчитель історії загальноосвітньої школи (с. Прилиманське Овідіопольського району Одеської обл.); ORCID: https://orcid.org/0000-0002-2738-9218; e-mail: argatyukt@ukr.net Сапожников Ігор Вікторович - доктор історичних наук, провідний науковий співробітник Відділу Криму та Північно-Західного Причорномор'я Інституту археології НАН України (м. Чорноморськ Одеської обл.); ORCID: https://orcid.org/0000-0003-3889-6714; e-mail: ssappog5@gmail.com

${ }^{1}$ Прудникова Е., Чигирин И. Катынь. Ложь, ставшая историей. Москва, 2011. С. 154-159.

${ }^{2}$ Бабич А. Пережить оккупацию. Одесса, 2020.

${ }^{3}$ Разорение и грабежи народного хозяйства и культурных ценностей оккупантами в Одессе и Одесской области // Одесса в Великой Отечественной войне Советского Союза: Сб. док. и матер. Т. 2: 17.X.1941-9.IV.1944. Одесса, 1949. С. 56-88.
} 
ховувала протягом багатьох років. Так, більш ніж красномовним є факт, що коли у 1960-х роках під час прокладання траншеї для бензопроводу до аеропорту в районі 6-го км Овідіопольського шосе, ківш екскаватора підняв на поверхню груду людських кісток і черепів, влада наказала все зарити й якнайшвидше забути про цю знахідку ${ }^{4}$.

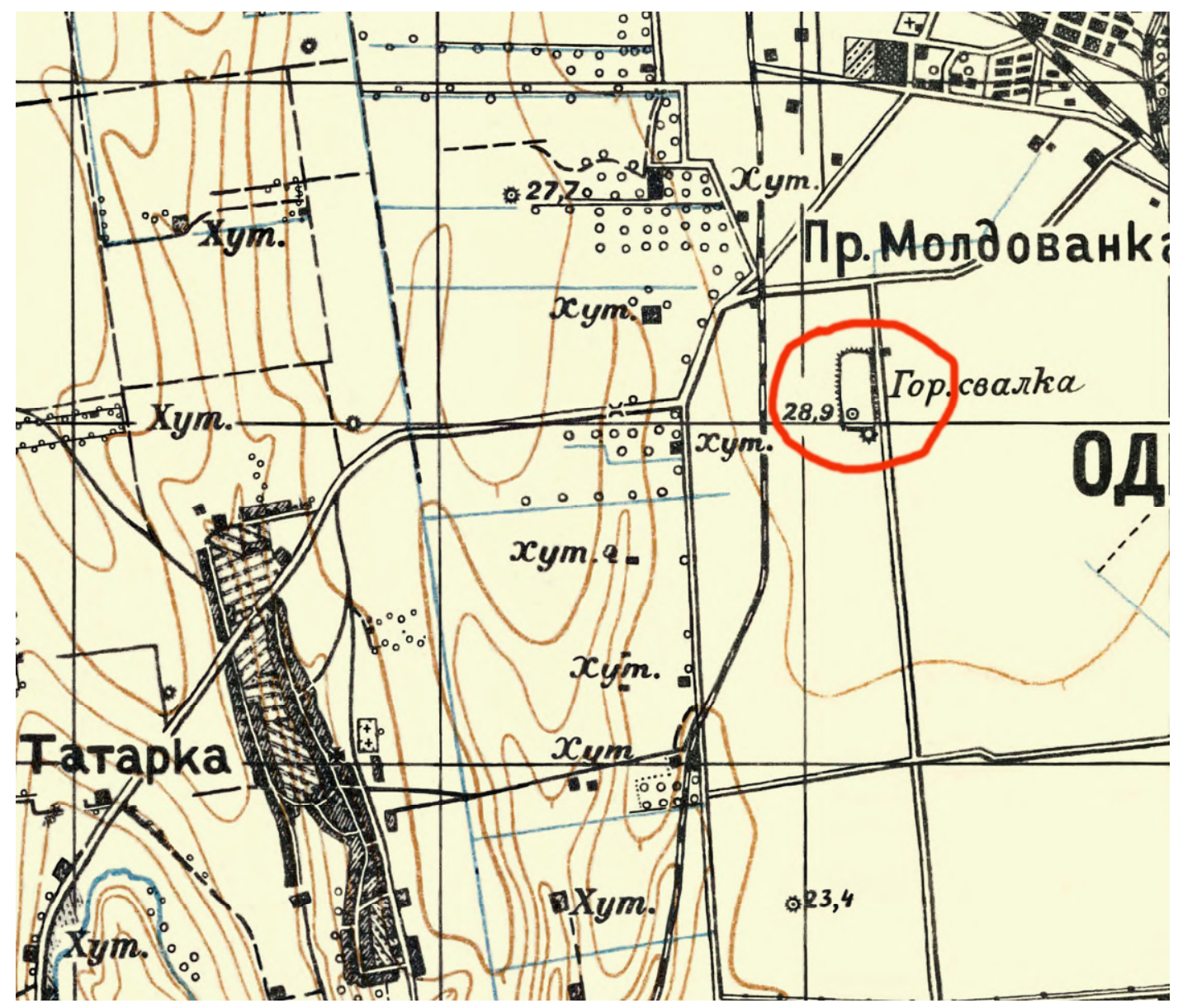

Рис. 1. Місце масових розстрілів під Одесою на карті 1917 р. (фрагмент)

Встановлено, що на початку XX ст. це місце мале назву Звалище (пізніше - Cmaре Звалище) $)^{5}$ і було пов'язане 3 курганом заввишки понад 5,0 м з геодезичним пунктом (мав абсолютну позначку +60-63 м), який на тогочасних і більш ранніх картах мав назву Могила Татарська, а поруч з південного сходу стояв ще один менший курган. Підкреслимо, що до прокладання неподалік залізниці з Одеси на Овідіополь у 1916 р. шлях на с. Татарку проходив повз цього місця, що власне й дало назву найбільшому з курганів ${ }^{6}$. При облаш-

\footnotetext{
${ }^{4}$ Жакова Т. Закатаем останки расстреляных // Вечерняя Одесса. 2007. № 119 (8659). 14 августа.

${ }^{5}$ У низці документів 1943 р. в якості орієнтиру фігурує урочище Школка (рум. «Spolka»; так зазвичай називали плодові чи виноградні розплідники), але на картах того його виявити не вдалося.

${ }^{6}$ Сапожников И. Курганы Хаджибея - Одессы на картах, планах и в описаниях конца XVIII - начала XIX вв. // Південний захід. Одесика. 2019. Вип. 27. С. 18, Рис. 9.
} 
туванні звалище обнесли з усіх боків прямокутним у плані валом і ровом, що вочевидь стало однією з причин використання цього майданчика площею до двох гектарів для таємних операцій. Під час дослідження означеної теми історикам слід мати на увазі, що на кінець 1930-х років ця місцевість входила до складу земель Потриваївської машинотракторної станції (МТC) ${ }^{7}$ Одеського району, с. Татарка знаходилось у 3,6-3,9 км на захід від нього, а власне місто Одеса (в районі залізничного переїзду) - у 2,0-2,2 км на північний схід, а також лише у 860 м на схід від нового терміналу аеропорту «Одеса» (Рис. 1; 2).

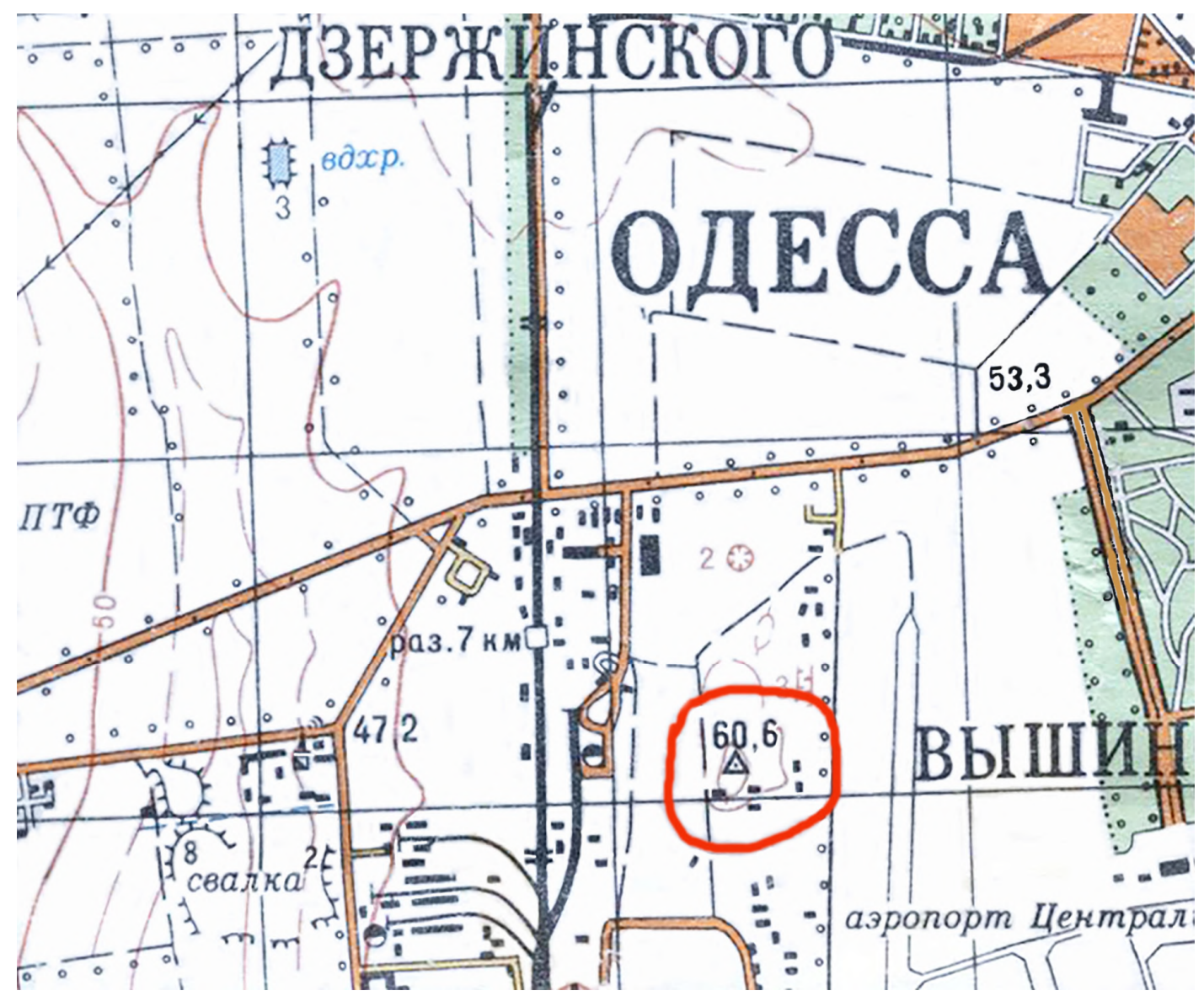

Рис. 2. Місце масових розстрілів під Одесою на карті 1977 р. (фрагмент)

Тільки з проголошенням незалежності України краєзнавці й історики отримали можливість висвітлювати «білі плями», пов'язані з масовими репресіями радянської влади. З’явилися перші повідомлення про жертви каральних органів і в Одесі: «Літопис Червоної калини» надрукував спогади німецького лікаря Макса Гартмана, учасника ексгумації жертв в Одесі і неподалік с. Татарка ${ }^{8}$. Того ж, 1993 р. їх передрукували в Одесі ${ }^{9}$ Ці свід-

\footnotetext{
${ }^{7}$ На честь червоного партизана М.Ф. Потриваєва, базувалася на колишній ділянці Вишинських.

${ }^{8}$ Гартман М. Більшовицькі злочини в Одесі // Літопис Червоної калини. Історико-краєзнавчий часопис. Львів, 1993. Ч. 3-4. С. 50-52.
} 
чення, а також деякі повідомлення одеських газет 1943 р. використали Д. Липчак ${ }^{10}$, Г. Бурнашов ${ }^{11}$, О. Падовська ${ }^{12}$, С. Аргатюк ${ }^{13}$ та ін.

Перейдемо до фактів. За результатами ексгумації 6 серпня 1943 р. А. Біркле ${ }^{14}$ склав «Предварительный отчет судебно-медицинской экспертизы в Татарке» ${ }^{15}$. На той момент там відкрили 42 загальні могильні ями і ще 10-12 намічені для розкопування. У кожній 3 них було близько 80 трупів (загалом 3500), але очікувалося, що загальна кількість вбитих може сягати до 5000. 3516 викопаних тіл комісія обстежила 486 і висновки були такими:

- причиною смерті були постріли у задню частину черепа і лише в окремих випадках - у потилицю;

- розстріл вівся з військового револьвера, що мав кулі з металевою гільзою калібру 7 мм, та зі ствольного револьвера із свинцевими кулями калібру 5,5 мм;

- зброя знаходилася у безпосередній близькості;

- криміналістичні дослідження показали, що термін перебування трупів у ямах становив 3,5-5 років, а також були жертви, що пролежали у землі 4,5-5 років (з 1938 р.);

- в ямах не виявлено личинок або комах, які завершували процес гниття, що свідчило про те, що страта відбувалася у холодну пору року, а трупи були поховані відразу після стрілянини;

- процес гниття затримався також через велику кількість трупів, похованих разом;

- 4886 обстежених трупів усіх було знайдено зі зв'язаними за спиною руками, за винятком одного, для якого не було знайдено жодної зв'язки, але від неї було видно сліди на руках;

- із загальної кількості розслідуваних трупів 7 були жінками та 479 чоловіками, один з яких виявися солдатом у військовій формі;

- 43 трупи мали документи, які засвідчували їх особи (виписки зі звітів про їх арешти), що дозволило їх впізнати;

- 3486 були перепоховані 385, ще 31 - не поховані;

- вік: 20-30 років - 60, 30-40 р. - 189, 40-50 р. - 186, старше - 81;

- усі ідентифіковані були мешканцями УРСР ${ }^{16}$.

\footnotetext{
${ }^{9}$ Трагедія, яку не приховати [спогади М. Гартмана] // Чорноморські новини. 1993. № 81 (2 жовтня). С. 2-3.

${ }^{10}$ Лапичак Д. Історія України в датах. Львів, 1995. С. 224.

${ }^{11}$ Бурнашов Г. Червоний терор на Україні. Івано-Франківськ, 2000. С. 27-28; Бурнашов Г. Злочини більшовизму. Івано-Франківськ, 2001. С. 39; Бурнашов Г. Досьє червоних визволителів. Івано-Франківськ, 2002. С. 22.

${ }^{12}$ ДеКАленДар: Перелік видатних дат з історії України / Падовська О. (упоряд.). Львів, 2006. С. 150.

${ }^{13}$ Аргатюк С.С. Татарка-Прилиманське: Нарис з історії села та навколишніх земель. Одеса, 2006. С. 123-128; Аргатюк С.С. Трагедія біля Татарки // Овідіопольський район: Енциклопед. довідник. Одеса, 2011. С. 293-294.

${ }^{14}$ Олександр Біркле (1896-1986) - лікар-криміналіст, професор. Народився у сімї̈ польського вигнанця. У 15 років переїхав до Австро-Угорщини, а потім до Румунії. Закінчив медичний факультет Бухарестського університету. Член Міжнародної комісії у розслідуванні справ про радянські вбивства у Катині, Вінниці й Одесі. 31944 по 1946 перебував у розшуку та переховувався від переслідування органів НКВС, потім за чужим паспортом виїхав до Швейцарії і далі до Аргентини. 1952 р. прибув до Вашингтону, де свідчив у справі розстрілів Катині. Був заочно засуджений на 20 років за військові злочини, і лише 1992 реабілітований. Див.: Toтa R.Jr. Cum a dus-o masacrul de la Katyn pe Rodica Marta în puşcărie // Jurnalul Național. 2009. 3 aprilie.

${ }^{15}$ Documente româneşti ale timpului despre atrocitâtile bolsevice din stanânga prutului // Інтернетресурс: www.morarup.narod.ru

${ }^{16}$ Ibidem.
} 
Відповідно до інформації одеських газет, хронологія подій, пов'язаних з розкопками могил жертв біля с. Татарка була такою. У квітні 1943 р. румунська окупаційна влада виявила сліди масових страт, які, вірогідно, здійснили органи НКВС. 23 квітня газета «Одесса» надрукувала замітку про відкриття нових фактів злочинів е Трансністрії, назвавши їх повторенням великого злочину Катиньського лісу ${ }^{17}$. Про неї повідомила майже вся преса окупованої частини України, а газета «Миргородські вісті» прямо назвала це місце «Другою Катинню» ${ }^{18}$.

На місце виїхав військовий претор м. Одеса, полковник Кока Ніколеску і за його ініціативи почали розкопки. 25 квітня описали місцезнаходження: «за сім кілометрів від Одеси, де за вказівкою місцевих мешканців, віднайдено місце у 300-400 кв. м, засипане будівельним сміттям, цеглою, розбитими консервним банками й ін. Під шаром у 75100 см виявлено звалені трупи людей, вбитих за наказом НКВС... 3 показів місцевих мешканців вдалося вияснити, що це місце добре охоронялося агентами НКВС, які не дозволяли рух по сусідньому шосе під час розстрілів невинних жертв... На місце розкопок прибули представники преси: шеф військової пропаганди локотилент-колонель Енеску з іншими представниками...»" . До Одеси з Берліну прибули спеціальні кореспонденти агентств ДНБ і «Стефані». На місце розкопок їх супроводжував журналіст Г. Пислару, а 29 квітня були надруковані більш детальні враження журналіста Євгена Адамова (Дод. 1$)^{20}$.

Роботи продовжили у травні, задіявши 200 місцевих робітників. 5 травня «Одеська газета» повідомила про покази колишнього агента $\mathrm{HKBC}^{21}$. «Голос правди» зазначив, що у 1940-1941 рр. Одеське ГПУ арештувало багатьох осіб, у тому числі німців, українців, болгар, румун з Бессарабії та Буковини. На початку жовтня 1941 р. в одеській тюрмі знаходилося біля 6000 в'язнів, яких, за свідченнями місцевих мешканців, розстріляли 1314 жовтня 1941 р., тобто за два дні до входу в Одесу румунсько-німецьких військ. Їх тіла не віднайшли, а тюрма виявилася пустою. Румунська судова влада ще не з'ясувала, чи знаходилися ці 6000 осіб у знайдених могилах 22 .

30 квітня спеціально створена Комісія приступила до вивчення жертв розстрілів біля дороги до Татарки. В їі складі були: заступник начальника Медико-санітарного управління уряду Трансністрії лікар К. Шапочкін, адміністратор відділу дезінфекції Н.І. Грубіану, начальник відділу медико-правової експертизи доцент I.I. Фідловський, представник жандармерії Одеської претури Г. Татарчук. У звіті відмічалося, що п'ять могил знаходилися на звалищі. Вони являли собою глибокі та широкі ями з вертикальними стінками і в кожній 3 них знаходилася значна кількість розкладених трупів. Чоловічий і жіночий суконний одяг, штани, нитки, жіночі шовкові блузи збереглися добре. Виявили навіть пальто і штани з того ж матеріалу. Такий одяг носили бессарабці та буковинці. Були також військові плащі, а біля ніг трупів черевики, чоботи з калошами й одяг з фабричної тканини. 3 предметів виявлені: металева чашка, коробка для мила, пенал для зубної

\footnotetext{
${ }^{17}$ Раскрытие большого преступления НКВД в Транснистрии // Одесса. 1943. № 95 (23 апреля). С. 4.

${ }^{18}$ Відкрито другий Катин // Миргородські вісті. 1943. № 30 (9 травня). С. 2.

${ }^{19}$ Раскрыто колоссальное преступление НКВД под Одессой // Одесса. 1943. № 96 (25 апреля). С. 4.

${ }^{20}$ Адамов Е. На поле мертвых: Отчет о поездке к месту зверского убийства, совершенного большевиками // Одесса. 1943. № 97 (29 апреля). С. 3.

${ }^{21}$ Жертвы Одесского НКВД // Одесская газета. 1943. № 103 (5 мая). С. 2.

${ }^{22}$ Братская могила в Татарке // Голос правды. 1943. № 2 (15 мая). С. 2.
} 
щітки тощо. У трупі з довгим волоссям (жінки) руки були перев'язані мотузкою. При огляді скелетів і черепів знайшлися очевидні ознаки вогнепальних поранень у потилицю. Рани на одних черепах мали виходи, а інші - ні. Зовнішній вигляд усіх трупів був однаковий.

3 огляду на питання, поставлені Військовою преторіальною службою, Комісія вилучила 4 черепи для спеціальних криміналістичних досліджень. Що стосується санітарних заходів у зв'язку з ексгумацією, Комісія вважала, що «скелетні трупи», очевидно, належали цілком здоровим людям, але з видимими ознаками смерті - стрілянини. Хоча самі собою вони не були небезпечними, з огляду на те, що ями були відкритими, і 3 настанням спекотних днів була вірогідність поширення продуктів розкладання трупів, вирішили за необхідне якомога швидше поховати ці трупи. Крім того, на думку Комісії, трупи не мали даних для ідентифікації, тому їх вирішили залишити на місцях, але заздалегідь обробити хлористим вапном, а для повнішої характеристики жертв провести детальну експертизу зразків одягу.

Експертизу провели завідувач кафедри судової медицини Одеського університету проф. Ф.М. Жмайлович і доцент I.І. Фідловський. На підставі детального обстеження та розтину 4 черепів лікарі зробили висновок, що усі особи, яким належали черепи, загинули у результаті пострілу в нижню частину шиї. У двох черепів були отвори з виходом у районі лівого ока та біля основи черепа, у двох інших виходи були відсутні. Постріли були зроблені з малокаліберної зброї на близькій відстані. Троє з них були чоловіками, а одна жінкою (всі віком від 20 до 45 років).

На 1 травня начальник спецслужби полковник Тр. Борческу подав звіт: «На місцевості під назвою «Spolka» [див. вище], розташованій біля залізниці на 7 км біля дороги Одеса-Овідіополь, між передмістям Татарки та аеродромом, були виявлені могили жертв НКВС... Із заяв мешканців околиць відомо, що органи НКВС привозили їх вночі закритою вантажівкою та кидали у загальну яму, яку негайно засипали, вирівнюючи поверхню. У той час рух транспорту по сусідній дорозі був заблокований і суворо охоронявся.

Розслідування встановило, що НКВС посилило страти після окупації Бессарабії та Північної Буковини. Іоан Халіп, Григоре Татарку та Александру Іванов, мешканці Бессарабії і Буковини, які мешкають в Одесі, після привезення їх на місце, впізнали трупи своїх депортованих родичів. Комісія після обстеження трупів дійшла висновку, що жертви були вбиті пострілом у потилицю з короткої відстані за 2-3 кроки; одяг знайдений в одній 3 могил нагадує національні строї бессарабців і буковинців. На даний час розкопки на цьому місці припинені...» ${ }^{23}$

А тепер звернемося до повідомлення Макса Гартмана, який прибув 4 травня з Бухаресту до Одеси. За його словами, він прибув 4 травня до Одеси з Бухаресту, написавши: «Інформація була скромна: в Одесі арештували агента НКВС, який, на свій захист, заявив, що він до тієї праці був змушений. Як доказ розповів він таку історію: “Однієї ночі 1938 року проходив я по залізничній лінії Аккерман-Одеса, яка проходить декількасот метрів на захід від летовища Одеса-Татарка. У місячному світлі я помітив, як у напрямку летовища під'їжджали великі чорні тягареві авта, затримуючись на вільній площі, що була

\footnotetext{
${ }^{23}$ Troncjtâ Cr. Glorie șitragedii: momente din istoria Serviciilor de informații și contrain formații române pe Frontul de Est, 1941-1944. Nemira, 2003. S. 119.
} 
завжди ізольована задля військових робіт, і там скидали щось, якісь великі темні предмети. Було також чути постріли. Коли я так приглядався, мене затримали і пізніше примусили стати агентом НКВС, на що я й згодився, бо це був єдиний спосіб порятунку”».

I далі: коли полковник К. Ніколеску сповістив про знахідку Бухарест, там прийняли рішення створити комісію у складі: 4 румуни - полковник Ніколеску, два підполковники і судовий лікар - професор доктор Біркле; два німці (один з них М. Гартман), три професори Одеського університету та судовий лікар. Для виконання земельних робіт задіяли 200 місцевих чоловіків і жінок. Дослідження біля Татарки проводилися 34 травня по 30 червня. Площа ділянки, на якій ховалися жертви, сягала 180 м завдовжки і 110 м завширшки. За оцінкою доктора А. Біркле, там знайшли свою смерть від 2 до 3 тисяч осіб. Поле 3 жертвами знаходилося на південь від шосе Одеса - Овідіополь, куди вела асфальтована дорога, яка закінчувалася за 500-700 м. За М. Гартманом: «Ми стояли на південному краї довгого поля, приблизно 800 м завдовжки та 400 м завширшки. Зі сходу на захід тягнулися 3 або 4 ряди земляних насипів і свіжої землі. Ціле поле було закидане купами сміття, заржавленими бляшанками і колючим дротом».

Пройшовши з К. Ніколеску 600 м на захід, вони зупинилися над ямами, що були довжиною 36 м і глибиною 70-90 см. На дні виднілися людські кістки, скелети, частково змішані з рештками одягу. Навіть не ознайомлений з більшовицькими методами М. Гартман, оглянувши залишки, відмітив, що майже всі люди вбиті пострілом у потилицю. На краю однієї з ям стирчала постать трупа, руки якого були зв'язані на плечах і при відкопуванні разом з мотузкою залишилися на дні могили. Мотузка товщиною 3 мм залишалася ще цілою. У кістках черепа виднівся отвір від пострілу ${ }^{24}$.

Розкопки велися із заходу на схід. При копанні ям до глибини 70-80 см траплялася вогка та брунатна земля. Під нею шарами лежали жертви, що були покидані одні на одних, головами у протилежні боки. Таких шарів було шість або й більше, на глибині 1,8 м яма скінчилась.

Після усунення насипної землі перед комісією відкрилися рівно складені в один шар сім щільно стиснутих до купи трупів. Усі були у цивільному одязі, повернені на спину і головами лежали на північ. Мовчки дивилися у відкриту могилу робітники, поглядаючи мутними, повними жаху та зворушення очима, то на лежачу жертву, то в обличчя сусіда. У тій могилі знайшли сім шарів трупів: у верхньому шарі вони лежали головами на північ, нижчі на південь, треті знову були укладені головами на північ, і так далі аж до дна. Всі жертви мали руки зв'язані на спині шнуром товщиною близько 2 мм. У потилиці кожного черепа виднівся стріляний отвір від 6 мм кулі. 56 жертв витягнуті 3 цієї могили. Вона мала 2,8 м у довжину і 1,7-1,8 м - в ширину. На 1 кубічний метр припадало 13 жертв.

Це були пересічні люди віком між 20-65 роками життя, переважно зодягнені в бідний одяг, з виголоднілим і схудлим тілом. Усі вони мали пов'язані на спині руки і були вбиті у потилицю. Серед них була лише одна жінка 38-40 років. У кишенях окремих жертв траплялися паперові клаптики з газет, що служили мабуть за папір для цигарок. На одному з таких паперів знайдено декілька слів вітання до рідних. Але імена не були вказані. У кишені іншої жертви знайшовся кисет 3 вишитою датою 30.05 та ім'ям

${ }^{24}$ Трагедія, яку не приховати... С. 2. 
«А. Романюк». Ці знахідки були негайно передані до Інституту судової медицини при Одеському університеті.

Всі присутні професори були єдиної думки і вважали, що трупи у могилах лежали приблизно 4-5 років, і майже в жодному випадку не було знайдено кулі у тілах, а також не було пошкоджень щелепи чи інших передніх частин голови. 3 цього комісія зробила висновок: вбивці мали дуже добрий вишкіл з анатомії, або чітко виконували наказ не залишати слідів. Вони мусили прикладати дуло зброї завжди в точному скісному напрямку, щоб куля виходила крізь одну з очних ям.

У другій могилі знайшли 68 жертв у такому ж самому положенні, як і попередні. Серед тих жертв знайшлися окремі речі, що дозволяли розпізнати деяких осіб, по старанно захованих, зашитих в одязі іменах, ті німі й неживі свідки могли виголосити останнє обвинувачення.

У третій могилі знайшли 123 жертви. Між ними троє у формі танкістів. Це були високі зростом і добре збудовані тілом юнаки віком до 23 років. При відкритті могили зверху над першим шаром, натрапили на труп дитини. Це була наймолодша жертва, більше таких випадків комісія не зафіксувала.

При розкопці іншої могили робітники раптом викопали кілька гільз. При докладному обстеженні в кутку могили знайдено ще 166 штук. Стало ясно, що звезені жертви розстрілювалися безпосередньо над могилами, а потім їх складали парами в ями. В іншо-

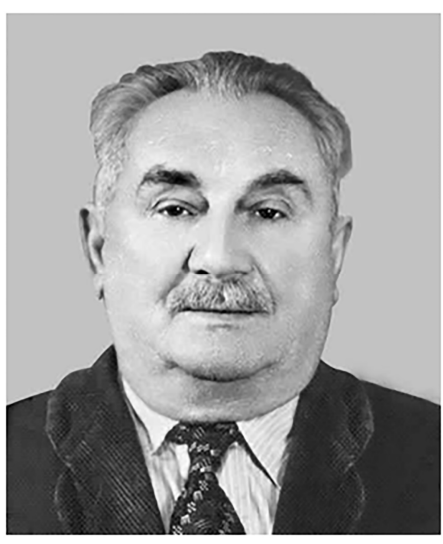

Рис. 3. М.М. Заєвлошин му кутку могили натрапили на складені речі, що їх принесли жертви з собою. Цей одяг просто скинули на верхній ряд замордованих людей і разом з ними присипали землею. Перший ряд в цій могилі містив 20 жертв, інші сім по 21, так що всіх разом 167 жертв. Кількість гільз сходилася 3 кількістю вбитих (недоставало лише однієі). Таким чином вдалось встановити, що розстріли біля Татарки проводилися неодноразово ${ }^{25}$.

«Татарська трагедія» мала й інші наслідки. Вже після визволення Одеси 6-х місцевих членів комісії, в основному одеських патологоанатомів, репресували органи НКВС як небажаних свідків. Провину за розстріли біля с. Татарки списали на румунів, а потім заборонили про цю подію взагалі згадувати. Така доля спіткала професора Михайла Миколайовича Заєвлошина (1886-1968: Рис. 3). Будучи заступником примаря Г.В. Пинті, він очолював медико-санітарну дирекцію одеської примарії та був вимушений приймати участь у роботі комісії, яка, до речі, своєї роботи не завершила. 21 березня 1945 р. він був засуджений. В обвинувальному вироку були підбиті усі провини, але особливе занепокоєння відділу контррозвідки 5-ї Повітряної армії викликала участь М.М. Заєвлошина у роботі Комісії по розкопках трупів: «з метою фальсифікації справи про масові розстріли громадян органами радянської влади». Суд присудив йому 15 років каторжних робіт і 5 років позбавлення громадянських прав 3 конфіскацією всього

\footnotetext{
25 Трагедія, яку не приховати... С. 2-3.
} 
майна. М.М. Заєвлошин був звільнений з табору лише у 1956 р. Останні роки життя мешкав у Білгороді-Дністровському ${ }^{26}$. Реабілітований посмертно у 1997 р.

У 2008 р. роботи на 6 км продовжила київська пошукова група «Меморіали України» (10 осіб на чолі з Ю. Федоровим і С. Денисенком) разом з активістами організації «Одеський меморіал» (О. Андросов та ін.). Ї̈̈ звіт не опублікований, але описані написи на знайдених речах: два мундштуки мали дату «1938» та ініціали «Д.К.»), гребінець - «Міша Г.», футляр для зубної щітки - літери «А.Е.». Зібрані кістки 1086 жертв три роки зберігались у контейнері підприємця Л. Єлагіної неподалік від розкопок ${ }^{27}$. Виділені 3 державного бюджету на експертизу залишків і їх перепоховання 400 тис. грн. «зникли» разом 3 організацією, яка самоліквідувалася після отримання коштів. Тому перепоховання провели члени організації «Пам'ять і слава» (керівник Л. Ігнатьєв) лише у жовтні 2011 р. на Західному цвинтарі Одеси, при чому кістки жертв склали у 82 домовини ${ }^{28}$.

Тут автори мають зауважити, що саме факти розстрілів у цьому районі почали піддаватися сумніву, зокрема їх передатовують пізнішим часом, щоб вважати винуватцями у вбивствах румунських військових. Показово, що автори таких тверджень частіше критикують не висновки експертів, а спогади очевидців і замітки журналіста Е. Адамова. Ми навмисно навели її повністю, щоб показати - це емоційні замальовки і найперші враження від розкритих могил, а не факти, доведені фахівцями (Дод. 1). Нам здається, що у нашій статті відповідних матеріалів наведено більш ніж достатньо, і тому ми не будемо розпочинати тут зайву дискусію з тими, хто користується такою «логікою»: «Напоминаем, что район носил красноречивое название Старая Свалка. Думаем, там еще и не то можно было найти...»" ${ }^{29}$.

Слід сказати також, що у 1943 р. згадана Комісія проводила розкопки й на II-му християнському кладовищі, де було виявлено три ями. У перших двох 7 серпня знайшли 22 напіврозкладених трупи, в основному молодих осіб віком від 17 до 22 років (тіло одного 3 них впізнала мати). На той час військове командування припускало, що на третій ділянці кладовища могло бути зарито до 4000 чоловік (Дод. 2).

На жаль, про ці дослідження, як і про розстріли у цьому місці, відомо набагато менше. Члени організації «Одеський меморіал» почали там пошук масових поховань у 1989 р. Майже випадково один з авторів цих рядків, на запрошення керівника групи M.М. Данилова, взяв участь у тих роботах в якості консультанта-археолога і пам'ятає таке. Пошуки велися у південній частині кладовища, приблизно в кінці головної алеї і на захід від неї, ближче до кам'яного паркану вздовж вул. Якова Бреуса. Тоді I.В. Сапожников за допомогою сталевого щупу знайшов, крім 1-2 вже розритих, ще декілька могил«лантухів», які мали вузькі гирла з розширенням до дна та глибину 3-4 м і більше (копали професіонали, вірогідно працівники цвинтаря). Роботам заважало те, що на той час ділянка була зайнята частково доглянутими похованнями 3 надгробками 1950-1960-х років і родичі померлих не були в захваті від «розкопок» між могилами. Наскільки відомо, зага-

\footnotetext{
${ }^{26}$ Профессор Заевлошин. Дело № 2470917-П // Смирнов В.А. Реквием ХХ века. Ч. 3. Одесса, 2016. С. 114, 117-118.

${ }^{27}$ Аргатюк С.С. Трагедія... С. 293-294.

${ }^{28}$ В Одессе похоронили жертв коммунистического террора. А вместе с ними множество вопросов // Інтернетpecypc: www.048.ua>news

${ }^{29}$ Прудникова Е., Чигирин И. Вказ. праця. С. 159.
} 
лом там вдалося виявити 17 невідомих раніше ям з останками жертв терору (по 10-12 тіл у кожній).

30.10.1997 р. на одній з братських могил, де перепоховані 147 ексгумованих жертв, встановили пам'ятний знак 3 трьох хрестів ${ }^{30}$. Згодом на цвинтарі постали дві меморіальних плити, на одній з яких вибито: «На цьому кладовищі покоїться прах жертв сталінських репресій, закатованих і розстріляних у 1930-1940-х роках...»" ${ }^{31}$.

Стосовно місць поховань, виявлених у 1943 р., то на підставі низки наведених фактів, можна зробити наступні висновки. По-перше, кидаються в очі суттєві відмінності між об’єктами біля Татарської Могили та на Другому кладовищі. Якщо великі могили першого об'єкта кістяками у 6-7 шарів дійсно можна пов'язати з місцями масових розстрілів, то на кладовищі, скоріше за все, таємно ховали тіла людей, вбитих у розташованій неподалік тюрмі. По-друге, не можна не помітити певні розходження в опублікованих цифрах. Так у 1943 р. допускалася наявність на кладовищі до 4000 вбитих, а реально було знайдено не більше 200 трупів. Тоді ж біля Татарської Могили кількість тіл у 52-54 ямах оцінювалось від 3500 до 5000, викопано було 516, з яких більшу частину перепоховали на тому самому місці. Однак, у 2008 р. там були ексгумовані (насправді грубо вириті) рештки 1068 осіб, а це свідчить лише про одне: тоді це місце було досліджене непрофесійно (без дотримання відповідних методик, належної фіксації та проведення наукових експертиз) і далеко не у повному обсязі. Отже ми впевнені, що крапку в цій жахливій історії ставити зарано, бо значна кількість тіл невинно страчених людей і досі лежить невідспіваними під купами сміття біля старого зруйнованого кургану.

\section{Sergey Argatiuk, Igor Sapozhnykov}

\section{The burial places of NKVD victims in Odessa: review of the press and documents of 1943}

Abstract: The article is devoted to a review and analysis of some episodes of Soviet repression in Odessa that took place in the 1930s and early 1940s, mainly through the prism of documents and the local press. A whole stack of indisputable facts about them was revealed to the general public in 1943, and then in the 1990s and 2000s, through excavations, reburial of the bodies of the dead and publication of documents, which formed a permanent public view of these phenomena. However, in recent years, they have been criticized and revised abroad, and for Odessa scientists and local historians, the topic itself has begun to disappear from the agenda. Therefore, the authors once again cite materials that in 1943 two burial places of victims of NKVD executions were investigated: at the city landfill near the Tomb of Tatar mound, near the 6 th $\mathrm{km}$ of Ovidiopol highway and at the $2^{\text {nd }}$ Christian cemetery. In order to fully reveal the topic, two newspaper articles are published, in which these places are described and

\footnotetext{
${ }^{30}$ Слово. 1997. № 44 (259). 31 жовтня.

${ }^{31}$ Кораблина B. На 2-м Христианском кладбище города Одессы... // Інтернетресурс: karta.psmb.ru>artiklesingle
} 
numerous findings and facts that directly indicate the time, organizers and performers are found there.

Keywords: Odessa, city landfill, Tatarska Mohyla mound, Second Christian Cemetery, research of mass burial sites, reaction of local press

\section{Е. Адамов. На поле мертвых}

Додаток 1

(отчет о поездке к месту зверского убийства, совершенного большевиками)

Машина плавно соскальзывает с подъема и вырывается за городскую черту. Позади остается блестящая линия рельс. Мы едем к полю мертвых.

Разрывая пряный воздух весны, машина стремительно мчится по старенькому потрепанному шоссе. В лицо ударяет пьяный запах полей. Слева кончаются последние постройки, и вот открывается ширь степей, вдоль дороги уже зазеленело. Цвет молодой зелени необыкновенно нежен и не хочется думать, что мы едем глядеть на ужасное злодеяние, на останки убитых людей

Наш «шофер», сотрудник военной пропаганды Теодор Мардари «выжимает скорость», и мы буквально летим, чувствуя, как шелестят шины. В полях оживление. То там, то сям встречаются пахари. Не отрываясь от труда, они смотрят нам вслед. На обочине дороги стоит старый крестьянский воз, задрав оглобли к небу.

Сворачиваем. На узкой проселочной дороге зелени еще больше, а по краям дороги бесконечно тянутся вспаханные свежие поля. Во всем чувствуется возрождающаяся жизнь природы, а мы едем на поле мертвых, чтобы зарегистрировать страшные преступления, совершенные нечеловеческим строем.

Машина сворачивает еще раз, и сбавив ход, прыгает по кочкам. Подъезжаем. Навстречу нам выходят солдаты. Проверяют документы и козыряют. Оставляем машину и медленно, обнажив головы, едем к широкой поляне, засыпанной строительным мусором, разбитыми заржавленными консервными банками, камнями и битым кирпичом. Хилая трава пробивается сквозь камни, оживляя мертвое поле. Фотограф на ходу готовит аппарат. Вокруг нет никаких селений, только узенькая дорожка, протоптанная в поле, тянется к Татарке. Легкий весенний ветерок шевелит засохшим, прошлогодним бурьяном. Тишь. Ширь. Весна.

Медленно подходим к одной четырехугольной яме. В сырости земли, глины и мусора скрюченный скелет и несколько черепов. Под ним еще несколько иссохнувших трупов, скрытых истлевшим тряпьем. Видно, что сюда нашвыряли людей, не думая.

Среди нас люди видавшие виды, но и они невольно вздрагивают при виде этого. На поверхность уже поднято несколько неопровержимых доказательств Лежит полуистлевшая обувь, изодранное тряпье, одежда. Здесь были убиты и женщины. Маленькие туфли простого фасона. Время и тление тронуло и обувь, и ясно можно определить, что найденные калоши неместного образца. Поднимаем одну калошу и стряхнув налипшую глину, читаем фирму «Кауром-Черновицы». Сразу становится многое ясным. Значит здесь были 
те, кого ночами вывозили из Буковины и Бессарабии. Вот, где нашли свою смерть люди, виновные только в том, что они жили в другой стране, другими мыслями и другими делами. В другой яме уже окончательно разложившийся скелет человека. Скелет уже рассыпался и на груде костей лежит обтянутая сморщенной сухой кожей рука, сжатая в кулак. Что думал этот человек умирая, никто никогда не узнает, но его сжатая, теперь уже истлевшая рука, до сего времени сохранила мужественную, напряженную ненависть к врагам человечества. Может быть эта рука, бессильная перед человекоподобными убийцами, сжимаясь перед смертью, символизировала собою неизбежную месть убийцамбольшевикам.

Среди истлевших скелетов остатки человеческого обихода. Несколько полуистлевших, рассыпающихся от прикосновения маленьких подушек. Простые, жестяные, похожие на тюремные, чайники. Все эти предметы заставляют предполагать, что люди были убиты, не ожидая смерти. Ведь НКВД часто делало так: вызывает группу арестованных и приказывает собираться в дорогу. Никто не знает, куда перевезут и осужденные теряются в догадках, а их вывозят на расстрел и с нечеловеческим садизмом уничтожают. Может быть и тут было так. Может быть эти несчастные жертвы были привезены сюда, под предлогом пересылки их в другую тюрьму и расстреляны. Время покрыло тайной это убийство, но следы не скрыты и подлые убийцы будут разоблачены.

Мы обходим другие ямы и рассматриваем скрюченные в ужасе, иссохнувшие скелеты людей. Кто они были при жизни? Как они жили? Кого любили и чем вызвана их жертва? Много тайн хранят эти небольшие, раскрытые до сего момента ямы, но ясно, что все это поле представляет из себя одну общую большую могилу, ибо убитые лежат в несколько рядов и в беспорядке набросанные.

Солдат глядит влажными глазами на эти остатки человеческих жизней и говорит нам, что здесь, по предположениям производящих раскопки, скрыто несколько тысяч убитых людей. Нужно снять весь слой мусора и камней и тогда откроется полная картина нечеловеческого преступления, совершенного большевиками. Один из нас обращает внимание на большие жестяные коробки, пробитые пулями навылет. Их встречается очень много в ямах вместе с убитыми. Сначала мы не обращаем внимание на эти коробки, но внезапно обнаруживаем в одной из них вместе с глиной и землей человеческий череп. Он глядит на нас широкими дырами глаз. Мысли теряются в догадках. И всплывает совершенно правдоподобное предположение - людей стреляли здесь, одевая им на головы эти жестяные маски. Встает полная ужаса картина. Убийцы боялись смотреть в глаза своим жертвам.

Начинаем осматривать полусгнившие одежды в надежде отыскать документы. Ищем старательно и настойчиво, но никаких бумаг отыскать нельзя. НКВДистские убийцы боялись оставлять следы. Видимо они знали, что рано или поздно их убийство будет раскрыто и они прятали следы.

В этих полуистлевших скелетах кроется величайшая тайна зверского уничтожения людей. Есть ли очевидцы этого страшного злодеяния и где отыскать их? Понятно только одно, что те «очевидцы», которые совершали это злодеяние, сегодня далеко от нашего города и никогда не возвратятся сюда. Не топтать им больше нашей земля. О, если бы отыскать сейчас такого «очевидца». Кажется собственными руками растерзал бы его. Вот 
обнаружено маленькое одеяльце грубого сукна с инициалами на краю. Буквы русские. По обнаруженным вещам видно, что здесь были убиты и русские люди. Найдена в маленькой полотняной сумке чайная чашка с маркой «Кременчуг».

В метрах пятистах от мертвого поля появился человек. Очевидно, это местный житель и я бегу ему навстречу. Это тракторист из Татарки. Спрашиваем, что он знает об этом месте. Он медленно опускает на землю котомку и говорит:

- «То було в году сороковом. Место это было оцеплено и нам забороняли ходить прямой дорогою в город, бо она пересекала это поле. Как идешь к городу, поутру, каждый раз земля свежевырытая, но стража не подпускает близко и никто не знал, что здесь делается. Думал сначала, что это раскопки какие-то большевики производят. Но днем никого, кроме стражи, не было и страшно строго запрещено было проходить близко от этого места. Осенью почти каждую ночь приходили сюда какие-то машины. Что они привозили никто не знал. Бабы, что живут на краю Татарки, говорили, что по ночам там выстрелы слышались, но сам не слышал».

Мы подводим его к одной из ям и показываем. Он испугано поднимает глаза и широко крестится.

- То, большевики сделали, видать здесь расстреливал, - высказывает он свое предположение. Но предполагать не нужно. Все ясно и без предположений.

В темные осенние ночи 1940 года, когда, чуя приближение войны, большевики начали «очищать» страну от «враждебных элементов», произошло у нас под Одессой страшное преступление. Сколько таких могил хранит тайна на русской земле.

С ненавистью к большевистским убийцам, с горячим желанием быть мстителями за миллионы убитых русских людей, покидаем мы поле мертвых, машина идет медленно. Но хочется стремительным движением показать торжество живого над мертвым. Мы все подавлены.

Мой спутник - журналист Пыслару, сидит, потупив глаза, и спрашивает: «Неужели они такие звери?». Наивный вопрос человека, не знающего, что такое большевизм!

Машина снова врывается в город, в свободный город, где каждый человек готовится к встрече Светлого Праздник Воскресения Господа Нашего Исуса Христа.

Одесса, 24 апреля 1943 2.

\section{Следы страшного большевистского преступления в Одессе}

Додаток 2

Еще в начале этого года румынские военные власти в Одессе стали получать сведения, по который предполагалось, что большевики при отступлении расстреляли большое количество арестованных и закопали часть их в Татарке, а часть на русском православном кладбище.

Помимо ведущихся сейчас раскопок в Татарке, где уже обнаружено много ям, в которых обнаружено большое количество расстрелянных, такие же раскопки стали производить недели две тому назад и на русском православном кладбище. В течение этих двух недель ничего не удалось обнаружить и только утром в субботу, 7 августа, удалось на- 
толкнуться на страшную находку. Сперва в одной, а потом и в другой яме обнаружено 22 полуистлевших трупа.

Весть об этом очередном большевистском злодеянии моментально облетела весь город и в воскресенье 8 августа на это кладбище направилось много граждан, семьи которых были арестованными большевиками и о их судьбе ничего не было известно.

Вот они эти 22 трупа. Они лежат на земле в два ряда. Многие из них лежат лицом к земле, со связанными назад руками. У всех виднеется на затылке запекшаяся кровь, видимо с ними покончили тем же выстрелом в затылок. По многим признакам можно заключить, что все это - молодежь 17-20 лет. У многих так и остались раскрытые челюсти. Видимо во время последнего крика, обращенного в пространство, их и застрелили.

У многих не совсем истлела одежда. Вот у одного юноши с русыми волосами сохранились синие брюки, военная гимнастерка. Говорят, что в воскресенье одна женщина обнаружила в нем своего сына, который был арестован за несколько дней до прихода румынских властей. В понедельник, 9 августа, на это страшное место также пришло большое количество людей, с целью опознать своих близких. Ввиду такого огромного стечения народа, военные власти временно прекратили доступ к извлеченным трупам, чтобы не мешать продолжать эти раскопки дальше. Раскопки все продолжаются в самом отдаленном углу кладбища на заброшенном участке 97. На наших глазах приступили к разрытию третьей ямы. Сколько еще удастся выкопать новых трупов? Как предполагает военное командование, на этом участке зарыто около 4000 человек, раскопки производят русские землекопы. Весь район раскопок охраняется военными частями. 